Research Article

\title{
Enhancement of Tainan 9 Peanut Seed Storability and Germination under Low Temperature
}

\author{
Parinee Jeammuangpuk $\left(\mathbb{D},{ }^{1}\right.$ Parichart Promchote ${ }^{D},{ }^{1}$ Juangjun Duangpatra $\left(\mathbb{D},{ }^{1}\right.$ \\ Tanapon Chaisan $\mathbb{D}^{\mathbb{D}},{ }^{1}$ Damrongvudhi Onwimol $\mathbb{D}^{1},{ }^{1}$ and Craig K. Kvien $\mathbb{D}^{2}$ \\ ${ }^{1}$ Department of Agronomy, Faculty of Agriculture, Kasetsart University, Bangkok 10900, Thailand \\ ${ }^{2}$ Department of Crop and Soil Sciences \& NESPAL, The University of Georgia Tifton Campus, Tifton, GA 31793, USA \\ Correspondence should be addressed to Parichart Promchote; parichart.pr@ku.th
}

Received 21 August 2020; Revised 6 October 2020; Accepted 8 October 2020; Published 29 October 2020

Academic Editor: Cristina Patan

Copyright (c) 2020 Parinee Jeammuangpuk et al. This is an open access article distributed under the Creative Commons Attribution License, which permits unrestricted use, distribution, and reproduction in any medium, provided the original work is properly cited.

\begin{abstract}
Low temperature condition during December to January can limit seed emergence and seedling establishment for peanut production in Thailand. The objective of this study was to determine the effects of peanut seed priming on seed germination and vigor under optimal and low temperature conditions before and after 9 months of storage. Tainan 9 peanut seeds were primed with salicylic acid (SA), ascorbate (ASA), $\mathrm{CaCl}_{2}$, or chitosan and tested for germination at $25^{\circ} \mathrm{C}$ (optimal temperature) and $15^{\circ} \mathrm{C}$ (low temperature) before and after a 9-month storage period. Seed priming with $50 \mathrm{mg} \cdot \mathrm{L}^{-1} \mathrm{SA}$ and $50 \mathrm{mg} \cdot \mathrm{L}^{-1} \mathrm{ASA}$ for $12 \mathrm{hours}$ before germinating improved germination at $15^{\circ} \mathrm{C}$ when compared to untreated seeds both before and after 9-month storage. The high seed quality, illustrated by high germination percentage, high seed vigor, and low mean germination time related to the low autoxidation substrates: lipoxygenase (LOX), malondialdehyde (MDA), and high antioxidants: superoxide dismutase (SOD) and catalase (CAT). It suggests that peanut seed priming with salicylic acid and/or ascorbate can improve seedling emergence and growth under low temperature conditions.
\end{abstract}

\section{Introduction}

Peanut cultivated in north and northeast Thailand may be exposed to soil temperatures below $25^{\circ} \mathrm{C}$ for $1-2$ weeks during the December to January planting season [1]. Temperatures below $16^{\circ} \mathrm{C}$ are known to reduce peanut germination percentage, germination rate [2], seedling establishment, seed set, and crop yield [3]. No germination was found when peanut germination temperatures fell below $11^{\circ} \mathrm{C}$ [4]. Temperatures below $10-15^{\circ} \mathrm{C}$ affect seed imbibition, enzyme activity, metabolism [5], and liquidity of membrane lipid [6]. Low temperatures are also known to induce reactive oxygen species (ROS) and oxidative damage to the membrane system of plants [7] that result in the loss of membrane integrity, solute leakage, and metabolic dysfunction [8]. Superoxide dismutase (SOD) and catalase (CAT) are antioxidants that improve the cold resistance of plants through inhibiting membrane lipid peroxidation [9] and eliminate ROS and free radicals [10]. Seed priming with some chemicals has been shown to improve seed germination under low temperatures in various crops [10-12]. Most of the priming methods were based on controlling seed hydration and preparing them to germinate before sowing. There are (i) "hydropriming" where seeds are soaked in water; (ii) "halopriming" where seeds are soaked in a solution of inorganic salts, i.e., $\mathrm{NaCl}, \mathrm{KNO}_{3}, \mathrm{CaCl}_{2}, \mathrm{CaSO}_{4}$; (iii) "osmopriming" where seeds are soaked for a certain period in solutions of sugar, sorbitol, or mannitol, polyethylene glycol (PEG) followed by air drying; and (iv) "hormonal priming" where seeds are pretreated with different hormones, i.e., salicylic acid, ascorbate, kinetin, etc. [13]. Guan et al. [14] reported that maize seed priming with 0.50\% chitosan for $60-64$ hours reduced mean germination time. Under chilling stress of $15^{\circ} \mathrm{C}$, maize seed priming with $50 \mathrm{ppm}$ salicylic acid reduced mean germination time and increased emergence percentage, soluble sugars, amylase, 
superoxide dismutase, and catalase activities [12]. Additionally, inbred line corn seed primed with $50 \mathrm{ppm}$ ascorbate and $50 \mathrm{~mm} \mathrm{CaCl} 2$ increased the germination percentage, germination index, and plumule length while reducing mean germination time at $10^{\circ} \mathrm{C}$ [15]. Seed priming with these chemicals helped to regulate seed metabolism through stimulating catalase and peroxidase enzyme activity, inhibiting leakage of ions through the cell membrane, accelerating water and nutrients uptake in roots, and reducing the reaction of lipid peroxidation [16, 17]. Most of Thai peanut varieties are sensitive to low temperatures, particularly during the germination stage. It is unclear if seed priming can improve peanut seed germination under low temperatures and how each priming agent might affect seed and seedling physiology. The objective of this research is to evaluate the effects of peanut seed priming on seed germination and seed vigor under low temperature conditions before and after 9 months of storage.

\section{Materials and Methods}

2.1. Plant Materials. Randomized Complete Block Designs (RCBD) were used in these experiments conducted at the Seed Laboratory, Department of Agronomy, Faculty of Agriculture, Kasetsart University, Thailand. The experiment included five priming methods with four replications. Tainan 9 peanut seeds at $6 \%$ moisture and $90 \%$ germination were soaked in (i) distilled water, (ii) $50 \mathrm{mg} \cdot \mathrm{L}^{-1}$ salicylic acid, (iii) $50 \mathrm{mg} \mathrm{L}^{-1}$ ascorbate, (iv) $50 \mathrm{~mm} \mathrm{CaCl}_{2}$, and (v) $0.5 \% \mathrm{w} / v$ chitosan at $27^{\circ} \mathrm{C}$ for 12 hours. The concentration of each priming agent was determined based on preliminary experiments (Tables S1-S8). After soaking, the seeds were dried back to $6 \%$ moisture at room temperature. Unprimed seeds were used as control. The primed and unprimed seeds were kept in plastic bags, sealed, and stored at $27^{\circ} \mathrm{C}$. After 9 months of storage, primed and unprimed seeds were analyzed.

\subsection{Seed Germination and Seedling Vigor Evaluation.} Seed germination was tested before and after the 9-month storage following the methods of ISTA [18]. One hundred seeds were used in the germination test for each replication. Moist sand (70\% moisture content and $3 \mathrm{~cm}$ deep) was put in an $18 \times 27 \times 10 \mathrm{~cm}$ plastic box. Fifty peanut seeds were then planted on the moist sand of each box and covered with $1 \mathrm{~cm}$ of uncompressed sand. The germination boxes were then incubated in a germination chamber at $25^{\circ} \mathrm{C}$ (optimal temperature) and $15^{\circ} \mathrm{C}$ (low temperature) under alternating cycle of 12-hour illumination and 12-hour darkness for 10 days. Germination counts were made at 5 days after seeding (DAS) and 10 DAS. Normal seedlings were those with emergence of true leaves from the sand and a normal shoot. Germination percentage was calculated from the number of normal seedlings.

Mean germination time (MGT) was conducted following the same general procedure used in the seed germination test, yet seedling evaluations were done every day. MGT was calculated according to the equation of Matthews and Khajeh-Hosseini [19]:

$$
\operatorname{MGT}=\left(\frac{\sum\left(G_{t} \times T_{t}\right)}{\sum G_{t}}\right),
$$

where $G_{t}$ is the number of germinated seeds on day $t$, and $T_{t}$ is time corresponding to $G_{t}$ in days. Shoot height and root length were measured manually with a ruler. Dry weights of shoot and root were determined after oven-drying at $80^{\circ} \mathrm{C}$ for 72 hours.

2.3. Electrolyte Leakage Measurement. Electrolyte leakage to evaluate membrane permeability was done according to ISTA [18]. Twenty-five seeds were separately placed in containers with $75 \mathrm{ml}$ of deionized water at $25^{\circ} \mathrm{C}$ for 24 hours. The electrical conductivity of solution $\left(\mu \mathrm{s} \cdot \mathrm{cm}^{-1}\right)$ was measured using EC meter.

2.4. Enzyme Analysis. One gram of ground peanut seeds was mixed with buffers for enzyme and substrate assays: Tris$\mathrm{HCl}$ buffer (100 mm, pH 8.0) for lipoxygenase (LOX), $50 \mathrm{~mm}$ sodium phosphate $(\mathrm{pH}$ 7.0) for catalase (CAT), $100 \mathrm{~mm}$ sodium phosphate buffer ( $\mathrm{pH}$ 6.4) for superoxide dismutase (SOD), and $0.1 \%$ trichloroacetic acid (TCA) for malondialdehyde (MDA). The samples were centrifuged at $4^{\circ} \mathrm{C}$ for $20,000^{\circ} \times \mathrm{g}$ and $30 \mathrm{~min}$. Supernatants after centrifuging were used for the assay.

LOX activity was determined using the modified method of Wang et al. [20]. To $0.1 \mathrm{ml}$ supernatants we added $2.85 \mathrm{ml}$ sodium phosphate buffer ( $100 \mathrm{~mm}, \mathrm{pH} 6.0)$ and $0.05 \mathrm{ml}$ mixture substrates $(0.01 \mathrm{ml}$ linoleic acid, $1 \mathrm{ml}$ $\mathrm{NaOH}(0.1 \mathrm{~N}), 0.005 \mathrm{ml}$ Tween-20, and $4 \mathrm{ml}$ distilled water). Blank is the $2.85 \mathrm{ml}$ sodium phosphate buffer $(100 \mathrm{~mm}$, $\mathrm{pH}$ 6.0) mixed with the $0.05 \mathrm{ml}$ mixture substrates. Increase in absorbance at $234 \mathrm{~nm}$ and $30^{\circ} \mathrm{C}$ was measured using a UV-160 Spectrophotometer (Shimadzu, Japan). The LOX specific activity was expressed as $\mathrm{U} / \mathrm{mg}$ protein, where one unit was expressed as $1 \mu \mathrm{mol}$ hydroperoxide formed per min at $30^{\circ} \mathrm{C}$.

SOD activity was determined using the method suggested by Ukeda et al. [21]. To the $1 \mathrm{ml}$ of supernatants we added $0.1 \mathrm{ml}$ of each substrate: sodium carbonate $(50 \mathrm{~mm}$, $\mathrm{pH}$ 8), $3 \mathrm{~mm}$ xanthine, $3 \mathrm{~mm}$ EDTA, $0.75 \mathrm{~mm}$ nitroblue tetrazolium salt (NBT), 15\% BSA, and SOD solution or water. The absorbance change at $560 \mathrm{~nm}$ was measured at $25^{\circ} \mathrm{C}$ for $20 \mathrm{~min}$. One unit of SOD was defined as the amount of enzyme that caused a 50\% decrease of the SOD-inhibitable NBT reduction. The specific activity was expressed as $\mathrm{U} / \mathrm{mg}$ protein.

CAT activity was measured according to Beers and Sizer [22] with some modifications. The analysis mixture consisted of $1 \mathrm{ml}$ supernatants, $2 \mathrm{ml}$ sodium phosphate buffer (50 mm, pH 7.0), $0.5 \mathrm{ml} \mathrm{H}_{2} \mathrm{O}_{2}(40 \mathrm{~mm})$, and $0.5 \mathrm{ml}$ of enzyme. The decomposition of $\mathrm{H}_{2} \mathrm{O}_{2}$ was measured by the decline in absorbance at $240 \mathrm{~nm}$. The specific activity was expressed as $\mathrm{U} / \mathrm{mg}$ protein, where one unit of catalase converts one $\mu \mathrm{mol}$ of $\mathrm{H}_{2} \mathrm{O}_{2}$ per min.

Protein content was determined following the method of Bradford [23] which used bovine serum albumin (BSA) as the standard protein. 
2.5. Determination of the Malondialdehyde (MDA) Content. The assay of MDA as an end product of lipid peroxidation was measured using the method described by Jiang et al. [24]. To $1 \mathrm{ml}$ supernatants of the samples we added $2 \mathrm{ml}$ of $0.5 \%$ thiobarbituric acid (TBA) in $15 \%$ trichloroacetic acid. The solution was heated at $95^{\circ} \mathrm{C}$ for 20 min, quickly cooled in an ice bath for $5 \mathrm{~min}$, and then centrifuged at 12,000 g for $10 \mathrm{~min}$ to clarify the solution. Absorbance at $532 \mathrm{~nm}$ was measured and subtracted from the absorbance at $600 \mathrm{~nm}$. The amount of MDA-TBA complex (red pigment) was calculated with an extinction coefficient of $155 \mathrm{~mm} / \mathrm{cm}$.

2.6. Statistical Analysis. The data were analyzed using analysis of variance (ANOVA). Mean comparison among priming treatments calculated using Fisher's LSD. The comparisons of seed quality from two germination conditions or from two storage months were determined using a $t$ test.

\section{Results}

3.1. Effects of Seed Priming on Germination. Peanut seed priming with $50 \mathrm{mg} \cdot \mathrm{L}^{-1}$ salicylic acid (SA), $50 \mathrm{mg} \cdot \mathrm{L}^{-1}$ ascorbate (ASA), $50 \mathrm{~mm} \mathrm{CaCl}_{2}$, and $0.5 \%$ chitosan was significantly different from the control in germination and mean germination time (MGT) when germinated at both $25^{\circ} \mathrm{C}$ and $15^{\circ} \mathrm{C}$ (Table 1). Primed seeds with SA and ASA germinated $100 \%$ and reduced mean germination time from untreated seeds about 1 day at $25^{\circ} \mathrm{C}$ (Table 1$)$. At $15^{\circ} \mathrm{C}$, the germination of primed seeds with $\mathrm{SA}, \mathrm{ASA}$, and $\mathrm{CaCl}_{2}$ was 97\%, 98\%, and 98\%, respectively. The control was significantly different at $86 \%$ germination. Seed priming with ASA showed the lowest MGT (Table 1). All the priming treatments stimulated seed germination and germinated faster than the untreated seeds (Table 1).

3.2. Effects of Seed Priming on Seedling Growth. Priming treatments with SA, ASA, $\mathrm{CaCl}_{2}$, and chitosan significantly increased seedling growth rate, shoot height, and root length of seedlings when compared to the untreated control (Table 2). The SA and ASA treatments outperformed the other priming treatments. Seed priming with SA showed the highest seedling shoot height when tested at both $25^{\circ} \mathrm{C}$ and $15^{\circ} \mathrm{C}$. Both SA- and ASA-primed seeds were the highest in seedling root length and seedling growth rate at $15^{\circ} \mathrm{C}$ (Table 2).

3.3. Effects of Seed Priming on Electrolyte Leakage (EL), Lipoxygenase (LOX) Activity, and Malondialdehyde (MDA) Content. All the primed seeds were significantly lower in electrolyte leakage, lipoxygenase activity, and malondialdehyde content than the untreated seeds (Table 3). The lowest electrolyte leakage was observed in SA-primed seeds, whereas seed priming with SA and ASA was the lowest in lipoxygenase activity and malondialdehyde content (Table 3). This information suggests that low free radicals (LOX, MDA) relate to high seed germination.
3.4. Effects of Seed Priming on Superoxide Dismutase (SOD) and Catalase (CAT) Activities. Superoxide dismutase and catalase are antioxidants. All the primed seeds were significantly higher in superoxide dismutase and catalase activities than those in the untreated seeds (Table 4). Seed priming with $\mathrm{SA}, \mathrm{ASA}, \mathrm{CaCl}_{2}$, and chitosan resulted in higher SOD than the untreated and hydroprimed seeds (Table 4). The highest CAT was detected in primed seeds with SA and ASA (Table 4). The high SOD and CAT in SAand ASA-primed seeds related to high seed germination.

3.5. Effects of Seed Priming on Germination and Seedling Vigor of Tainan 9 Peanut Seeds after Nine Months of Storage. After 9 months of storage, peanut seed priming with SA, ASA, $\mathrm{CaCl}_{2}$, and chitosan was significantly different in germination, mean germination time, seedling shoot height, seedling root length, and seedling growth rate at both $25^{\circ} \mathrm{C}$ and $15^{\circ} \mathrm{C}$ conditions (Figure 1). Seed priming with SA and ASA showed the highest germination percentages (Figure 1(a)) and seedling growth rates (Figure $1(\mathrm{e})$ ) at $25^{\circ} \mathrm{C}$ and $15^{\circ} \mathrm{C}$ for both before and after 9 months of storage. Seed priming with ASA resulted in the lowest mean germination time (Figure 1(b)), whereas seed priming with SA resulted in the highest seedling shoot height at low temperature of $15^{\circ} \mathrm{C}$ after 9 months of storage (Figure 1(c)). Additionally, seed priming with SA showed greater seedling root length than that of primed seed with ASA at both $25^{\circ} \mathrm{C}$ and $15^{\circ} \mathrm{C}$ (Figure 1(d)). Notably, the primed seeds with SA and ASA after 9 months of storage maintained seed quality similar to seeds at 0 months of storage.

\section{Discussion}

Seed priming improved peanut seed germination. Hormonal priming peanut seeds with salicylic acid (SA) and ascorbate (ASA) enhanced seed germination (Table 1), seedling shoot height, seedling root length, and seedling growth rate (Table 2) and also reduced mean germination time (MGT) under low temperatures $\left(15^{\circ} \mathrm{C}\right)$ when compared to the control (Table 1). The priming may control hydration levels in seeds that generate metabolic activities necessary for germination [25]. The SA, ASA, and $\mathrm{CaCl}_{2}$ primed seed showed high germination percentages and low MGT under low temperature stress conditions, similar to the studies in rice [26, 27], corn [12, 15, 28], and S. miltiorrhiza [29]. Salicylic acid is an antioxidant that inhibits oxidative reactions, helps regulate cell growth (cell enlargement and division), and activates amino acids and proteins [30] that help protect the cell structure [31]. ASA may protect and prevent oxidative deterioration of lipids and maintain structural and functional integrity of membrane cells [16].

Low electrolyte leakage (EL) in SA-primed seeds indicates lower membrane damage under low temperature than untreated seeds (Table 3). Enhanced electrolyte leakage is considered to be a symptom of stress-induced membrane damage and deterioration [32, 33]. Chilling conditions may cause an increase in reactive oxygen species (ROS), inducing oxidative damage to the membrane system of plants [7]. 
TABLE 1: Effects of seed priming on germination percentage and mean germination time of Tainan 9 peanut seeds at $25^{\circ} \mathrm{C}$ and $15^{\circ} \mathrm{C}$ before 9 months of storage.

\begin{tabular}{|c|c|c|c|c|c|c|}
\hline \multirow{2}{*}{ Treatments } & \multicolumn{3}{|c|}{ Germination (\%) } & \multicolumn{3}{|c|}{ Mean germination time (days) } \\
\hline & $25^{\circ} \mathrm{C}$ & $15^{\circ} \mathrm{C}$ & Average & $25^{\circ} \mathrm{C}$ & $15^{\circ} \mathrm{C}$ & Average \\
\hline Untreated & A $90.00 d$ & A $86.50 c$ & $88.25 c$ & A $8.06 b$ & B $9.25 \mathrm{e}$ & $8.66 \mathrm{~d}$ \\
\hline Hydropriming & A $92.50 c$ & B $88.00 \mathrm{c}$ & $90.25 c$ & A $8.05 b$ & B $8.84 d$ & $8.45 \mathrm{~cd}$ \\
\hline $\mathrm{SA}\left(50 \mathrm{mg} \cdot \mathrm{L}^{-1}\right)$ & A $100 a$ & B $96.75 a$ & $98.38 \mathrm{a}$ & A $6.80 \mathrm{a}$ & B $7.64 \mathrm{~b}$ & $7.22 \mathrm{a}$ \\
\hline ASA $\left(50 \mathrm{mg} \cdot \mathrm{L}^{-1}\right)$ & A $100 a$ & A $98.50 a$ & $99.25 \mathrm{a}$ & A $6.83 a$ & B $7.22 a$ & $7.03 a$ \\
\hline $\mathrm{CaCl}_{2}(50 \mathrm{~mm})$ & A $96.00 \mathrm{~b}$ & A $98.00 a$ & $97.00 \mathrm{ab}$ & A $8.00 b$ & B $8.56 c$ & $8.28 \mathrm{~b}$ \\
\hline $0.5 \%$ chitosan & A $97.50 \mathrm{~b}$ & B $92.00 \mathrm{~b}$ & $94.75 b$ & A $8.03 b$ & B 8.49 c & $8.26 b$ \\
\hline Average & A 96.00 & B 93.29 & & A 7.63 & B 8.33 & \\
\hline $\mathrm{LSD}_{0.05}$ & 2.44 & 3.79 & & 0.19 & 0.25 & \\
\hline CV (\%) & 1.69 & 2.69 & & 1.65 & 2.01 & \\
\hline
\end{tabular}

Means within each column followed by the same lowercase letters are not significantly different at $P<0.05$ by LSD. Means within each row followed by the same uppercase letters are not significantly different at $P<0.05$ by $t$-test.

TABLE 2: Effects of seed priming on shoot height, root length, and seedling growth rate of Tainan 9 peanut seeds at $25^{\circ} \mathrm{C}$ and $15^{\circ} \mathrm{C}$ before 9 months of storage.

\begin{tabular}{|c|c|c|c|c|c|c|c|c|c|}
\hline \multirow{2}{*}{ Treatments } & \multicolumn{3}{|c|}{ Shoot height $(\mathrm{cm})$} & \multicolumn{3}{|c|}{ Root length $(\mathrm{cm})$} & \multicolumn{3}{|c|}{ Seedling growth rate (mg/seedling) } \\
\hline & $25^{\circ} \mathrm{C}$ & $15^{\circ} \mathrm{C}$ & Average & $25^{\circ} \mathrm{C}$ & $15^{\circ} \mathrm{C}$ & Average & $25^{\circ} \mathrm{C}$ & $15^{\circ} \mathrm{C}$ & Average \\
\hline Untreated & A $4.58 f$ & A $3.11 \mathrm{f}$ & $3.85 f$ & A $4.67 d$ & B $3.56 \mathrm{~d}$ & $4.12 \mathrm{~d}$ & A 172 c & B $42 \mathrm{~b}$ & $107.00 \mathrm{c}$ \\
\hline Hydropriming & A $4.88 \mathrm{e}$ & B $3.29 \mathrm{e}$ & $4.09 \mathrm{e}$ & A $7.00 \mathrm{c}$ & B $3.65 d$ & $5.56 c$ & A $212 b c$ & B $48 \mathrm{~b}$ & $130.00 \mathrm{~b}$ \\
\hline $\mathrm{SA}\left(50 \mathrm{mg} \cdot \mathrm{L}^{-1}\right)$ & A $6.08 \mathrm{a}$ & B $4.55 \mathrm{a}$ & $5.32 \mathrm{a}$ & A7.65ab & B $4.79 \mathrm{a}$ & $6.22 \mathrm{a}$ & A $324 a$ & B $87 \mathrm{a}$ & $205.50 \mathrm{a}$ \\
\hline ASA $\left(50 \mathrm{mg} \cdot \mathrm{L}^{-1}\right)$ & A $5.75 b$ & B $4.16 \mathrm{~b}$ & $4.96 \mathrm{~b}$ & A $7.85 a$ & B $4.55 b$ & $6.20 \mathrm{a}$ & A $321 \mathrm{a}$ & B $82 \mathrm{a}$ & $201.50 \mathrm{a}$ \\
\hline $\mathrm{CaCl}_{2}(50 \mathrm{~mm})$ & A $5.08 \mathrm{~d}$ & B $3.55 \mathrm{~d}$ & $4.32 \mathrm{~d}$ & A $6.78 c$ & B $4.00 \mathrm{c}$ & $5.39 c$ & A $256 b$ & B $55 b$ & $155.50 \mathrm{~b}$ \\
\hline $0.5 \%$ chitosan & A $5.37 \mathrm{c}$ & B $4.07 \mathrm{c}$ & $4.72 \mathrm{c}$ & A $7.48 b$ & B4.65ab & $5.83 \mathrm{~b}$ & A 240 b & B $50 \mathrm{~b}$ & $145.00 \mathrm{~b}$ \\
\hline Average & A 5.29 & В 3.79 & & A 6.91 & B 4.20 & & A 254.17 & B 60.67 & \\
\hline $\mathrm{LSD}_{0.05}$ & 0.18 & 0.06 & & 0.27 & 0.23 & & 59.61 & 15.77 & \\
\hline CV (\%) & 2.32 & 1.05 & & 2.59 & 3.70 & & 15.56 & 17.24 & \\
\hline
\end{tabular}

Means within each column followed by the same lowercase letters are not significantly different at $P<0.05$ by LSD. Means within each row followed by the same uppercase letters are not significantly different at $P<0.05$ by $t$-test.

TABLE 3: Effects of seed priming on electrolyte leakage (EL), lipoxygenase activity (LOX), and malondialdehyde (MDA) content of peanut seed priming before 9 months of storage.

\begin{tabular}{|c|c|c|c|}
\hline Treatments & $\mathrm{EL}(\mu \mathrm{s} / \mathrm{cm})$ & LOX (units/mg protein) & $\operatorname{MDA}\left(\mathrm{nmol}^{-1} / \mathrm{ml}\right)$ \\
\hline Untreated & $19.64 d$ & $1.41 \mathrm{c}$ & 3.91d \\
\hline Hydropriming & $15.65 c$ & $1.44 \mathrm{c}$ & $2.52 \mathrm{c}$ \\
\hline $\mathrm{SA}\left(50 \mathrm{mg} \mathrm{L}^{-1}\right)$ & $7.93 a$ & $0.97 \mathrm{a}$ & $1.58 \mathrm{ab}$ \\
\hline ASA $\left(50 \mathrm{mg} \mathrm{L}^{-1}\right)$ & $13.48 \mathrm{~b}$ & $0.95 \mathrm{a}$ & $1.47 \mathrm{a}$ \\
\hline $\mathrm{CaCl}_{2}(50 \mathrm{mM})$ & $14.92 \mathrm{bc}$ & $1.19 \mathrm{~b}$ & $2.25 \mathrm{bc}$ \\
\hline Chitosan $(0.5 \% w / v)$ & $13.33 \mathrm{~b}$ & $1.26 \mathrm{bc}$ & $2.18 b c$ \\
\hline $\mathrm{LSD}_{0.05}$ & 1.89 & 0.20 & 0.72 \\
\hline CV (\%) & 8.84 & 9.17 & 17.25 \\
\hline
\end{tabular}

Means within each column followed by the same lowercase letters are not significantly different at $P<0.05$ by LSD.

Excessive reactive oxygen has negative effects on cell structure and metabolism and also causes damage to proteins, DNA, and membrane lipids [34]. Chilling conditions also result in membrane integrity losses leading to solute leakage and metabolic dysfunction. The integrity of intracellular organelles is also disrupted and leads to the loss of compartmentalization, reduction, and impairing of protein assembly and other general metabolic processes [8].

Peanut seed priming with SA and ASA showed the lowest lipoxygenase activity (LOX) and malondialdehyde content (MDA) (Table 3). This suggests the treatments may help maintain cell membrane stability through restriction of lipid peroxidation [35]. The concentration of MDA content is an indicator of lipid peroxidation in plant cells $[32,36]$. The decline of the MDA concentrations in the Tainan 9 peanut seed under low-temperature stress indicates that seed priming with SA and ASA reduced lipid peroxidation. Similar to the study by Elkelish et al. [37], ASA mediated oxidative damage by lowering the electrolyte leakage and lipid peroxidation. Li et al. [38] reported that coating maize 
TABLE 4: Effects of seed priming on superoxide dismutase (SOD) and catalase (CAT) activities before 9 months of storage.

\begin{tabular}{|c|c|c|}
\hline Treatments & SOD (units/mg protein) & CAT (units/mg protein) \\
\hline Untreated & $0.067 \mathrm{c}$ & $0.63 \mathrm{~d}$ \\
\hline Hydropriming & $0.096 \mathrm{bc}$ & $1.23 \mathrm{c}$ \\
\hline $\mathrm{SA}\left(50 \mathrm{mgL}^{-1}\right)$ & $0.132 \mathrm{ab}$ & $2.34 \mathrm{a}$ \\
\hline ASA $\left(50 \mathrm{mgL}^{-1}\right)$ & $0.139 \mathrm{a}$ & $2.40 \mathrm{a}$ \\
\hline $\mathrm{CaCl}_{2}(50 \mathrm{~mm})$ & $0.123 \mathrm{ab}$ & $1.55 \mathrm{~b}$ \\
\hline Chitosan $(0.5 \% w / v)$ & $0.118 \mathrm{ab}$ & $1.17 \mathrm{c}$ \\
\hline $\mathrm{LSD}_{0.05}$ & 0.04 & 0.29 \\
\hline CV (\%) & 18.67 & 10.39 \\
\hline
\end{tabular}

Means within each column followed by the same lowercase letters are not significantly different at $P<0.05$ by LSD.
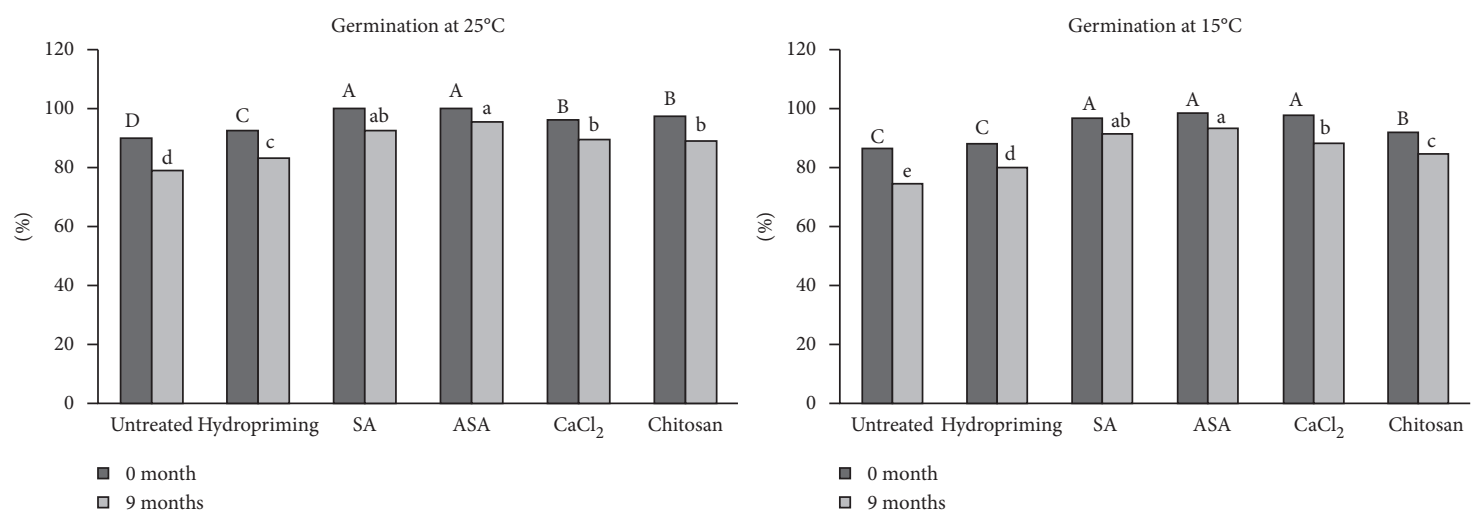

(a)
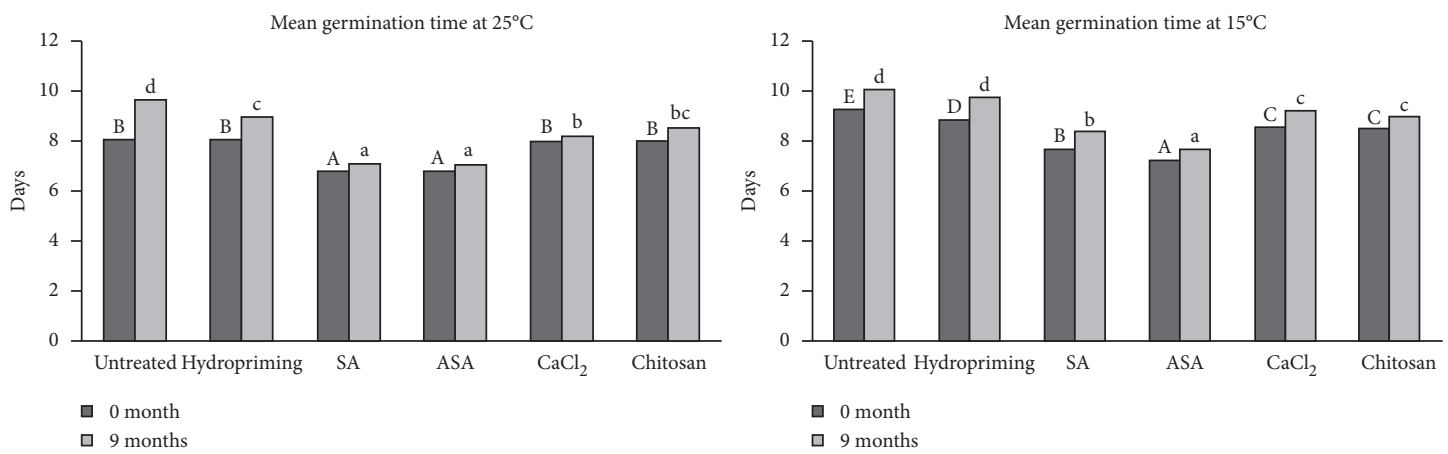

(b)
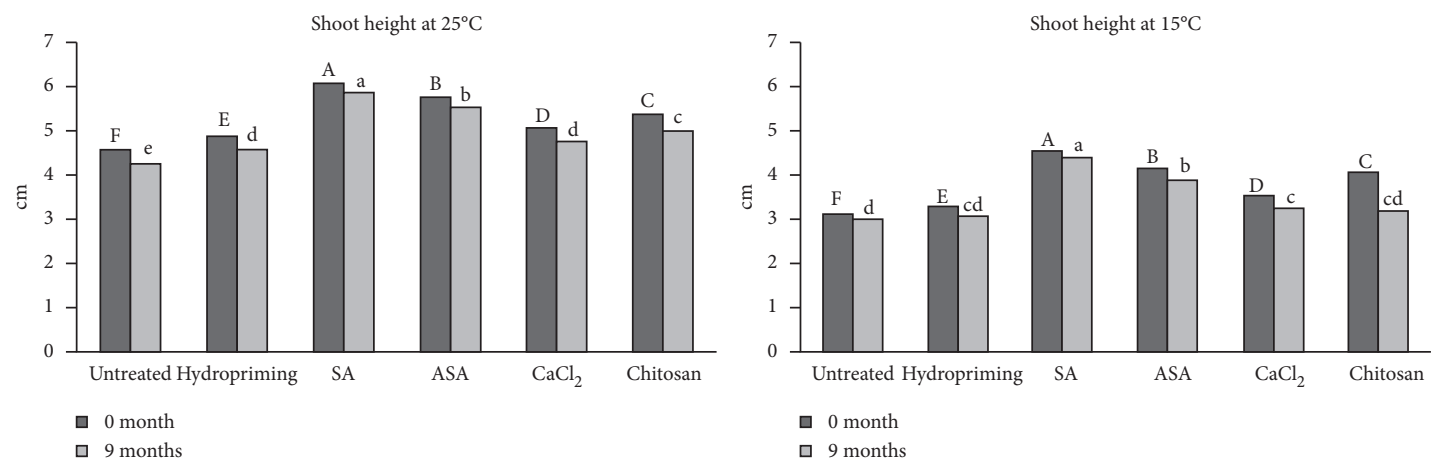

(c)

FIgURE 1: Continued. 

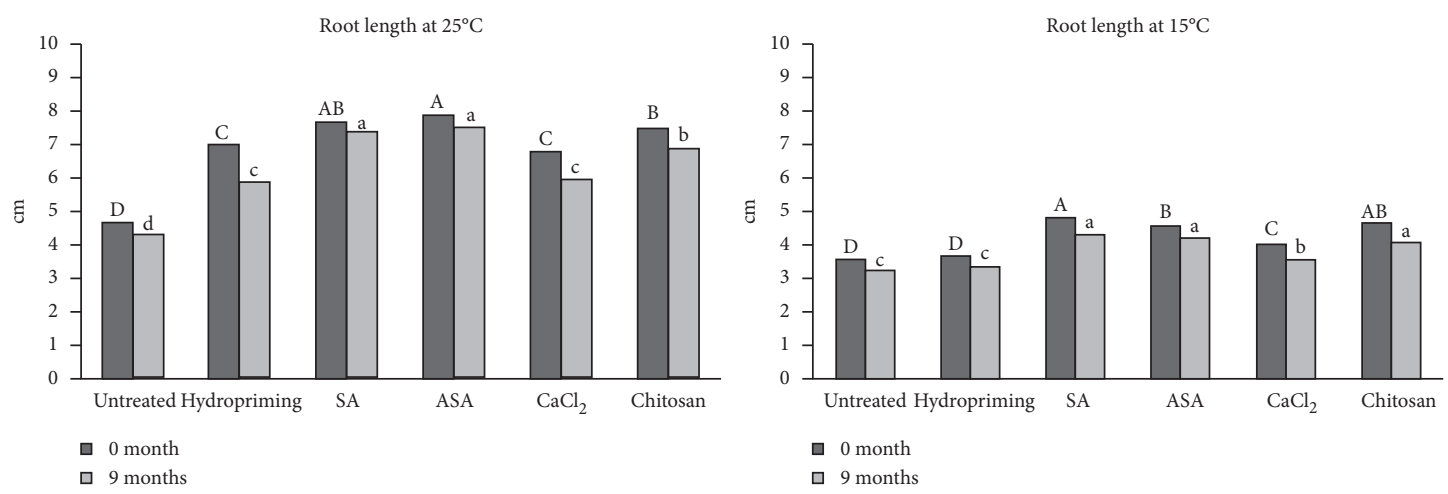

(d)
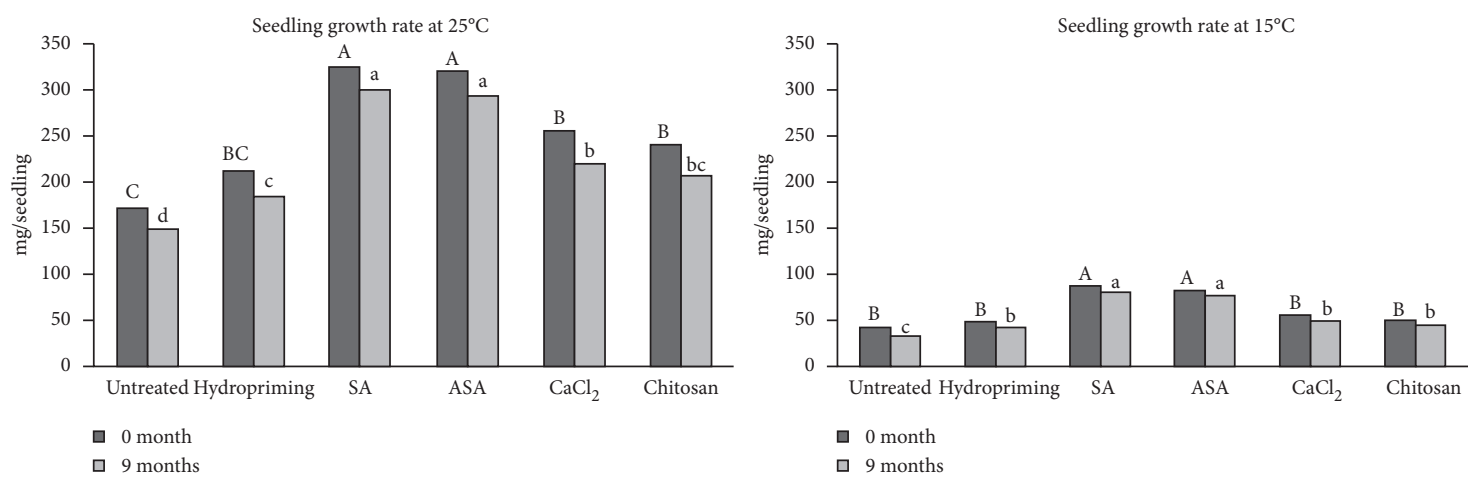

(e)

FIGURE 1: Effects of seed priming on germination, mean germination time, shoot height, root length, and seedling growth rate of Tainan 9 peanut seeds after nine months of storage when germinated at $25^{\circ} \mathrm{C}$ and $15^{\circ} \mathrm{C}$. Means among bar charts followed by the same uppercase (lowercase) letters are not significantly different at $P<0.05$ by LSD for 0 -month ( 9 -month) storage.

seed with a cold-tolerant agent reduced MDA accumulation in seeds geminated under low temperatures. The accumulation of MDA is related to superoxide dismutase (SOD) and catalase (CAT) enzyme activities, decreases in membrane damage (as indicated by low MDA concentration), and the higher activities of antioxidative enzymes [36].

Seed priming with SA and ASA was the highest in SOD and CAT activities under low temperature (Table 4) indicating an efficient scavenging system. SA-induced intrinsic heat or cold tolerance may be aided by maintenance of relatively higher activities of antioxidants [39]. Our results are similar to Farooq et al. [12] who noted that maize seed priming with $50 \mathrm{mg} \cdot \mathrm{L}^{-1}$ salicylic acid solution increased emergence percentage, reduced mean germination time, and increased amylase activity, soluble sugars, superoxide dismutase, and catalase activity at $27^{\circ} \mathrm{C}$ (optimal temperature) and at $15^{\circ} \mathrm{C}$ (chilling stress). The SOD and CAT helped to eliminate reactive oxygen species (ROS) and free radicals during stress $[10,16,40,41]$. These antioxidants potentially inhibited membrane lipid peroxidation [9] and protected the plant from oxidative damage under chilling stress [39-41]. Nonetheless, the physiological response of plants to cold stress condition is complex. Our research only evaluated SOD as the first and second enzymes involved in the antioxidant defense process $[16,42,43]$. Other enzymatic antioxidants (i.e., ascorbate peroxides, APX; peroxidase, POD; and glutathione reductase, GR) and nonenzymatic antioxidants (i.e., ascorbate, ASA; glutathione, GSH; and guaiacol peroxidase, $\mathrm{POX}$ ) also improved seed germination under cold stress which these antioxidant contents related to the increase of SOD and CAT [12, 44-51].

\section{Conclusions}

Tainan 9 peanut seed priming with $50 \mathrm{mg} \cdot \mathrm{L}^{-1}$ salicylic acid and $50 \mathrm{mg} \cdot \mathrm{L}^{-1}$ ascorbate for 12 hours improved seed quality when germinated at low temperature of $15^{\circ} \mathrm{C}$ compared to untreated seeds and other treatments. The primed seeds had the highest germination percentage, seedling shoot height, seedling root length, and seedling growth rate and the lowest in mean germination time. The high-quality primed seed also had low electrolyte leakage, lipoxygenase activity, malondialdehyde content, and high superoxide dismutase and catalase activities.

\section{Data Availability}

The complete dataset used to support the findings of this study are available from the corresponding author upon request.

\section{Conflicts of Interest}

The authors declare that they have no conflicts of interest regarding the publication of this paper. 


\section{Acknowledgments}

The authors thank the Mae-Ruay Snack Food Factory Co., Ltd., for granting a Ph.D. scholarship to the first author.

\section{Supplementary Materials}

The supporting information about the effects of different concentrations of each priming agent on seed quality is given in Supplementary Tables S1-S8. (Supplementary Materials)

\section{References}

[1] Meteorological Department of Thailand, Data Climate Statistics for Sakon Nakhon, http://www.tmd.go.th/province_ weather_stat.php?StationNumber=48356, 2016.

[2] P. Promchote, J. Authrapun, S. Rungmekarat et al., "Planting peanut after rice," Department of Agronomy, Faculty of Agriculture, Kasetsart University, Bangkok, Thailand, Technical Documents: Promoting and Increasing the Efficiency of Peanut Production in the Northeastern Thailand Project, 2014.

[3] G. S. Sanghera and S. H. Wani, "Innovative approaches to enhance genetic potential of rice for higher productivity under temperature conditions of Kashmir," The Journal of Plant Science and Research, vol. 24, pp. 99-113, 2008.

[4] D. L. Ketring, "Temperature effects on vegetative and reproductive development of peanut ${ }^{1,1}$," Crop Science, vol. 24, no. 5, pp. 877-882, 1984.

[5] R. C. Herner, "The effects of chilling temperatures during seed germination and early seedling growth," in Chilling Injury of Horticultural Crops, C. Y. Wang, Ed., pp. 51-63, CRC Press, Boca Raton, FL, USA, 1990.

[6] J. M. Lyons, "Chilling injury in plants," Annual Review of Plant Physiology, vol. 24, no. 1, pp. 445-466, 1973.

[7] R. R. Wise, "Chilling-enhanced photooxidation: the production, action and study of reactive oxygen species produced during chilling in the light," Photosynthesis Research, vol. 45, no. 2, pp. 79-97, 1995.

[8] A. Kacperska, "Metabolic consequences of low temperature stress in chilling-insensitive plants," in Low Temperature Stress Physiology in Crops, P. H. Li, Ed., pp. 27-40, CRC Press, Boca Raton, FL, USA, 1989.

[9] T. K. Prasad, "Mechanisms of chilling-induced oxidative stress injury and tolerance in developing maize seedlings: changes in antioxidant system, oxidation of proteins and lipids, and protease activities," The Plant Journal, vol. 10, no. 6, pp. 1017-1026, 1996.

[10] J. Hu, X. J. Xie, Z. F. Wang, and W. J. Song, "Sand priming improves alfalfa germination under high-salt concentration stress," Seed Science and Technology, vol. 34, no. 1, pp. 199-204, 2006.

[11] M. Farooq, S. M. A. Basra, and K. Hafeez, "Seed invigoration by osmohardening in coarse and fine rice," Seed Science and Technology, vol. 34, no. 1, pp. 181-187, 2006.

[12] M. Farooq, T. Aziz, S. M. A. Basra, M. A. Cheema, and H. Rehman, "Chilling tolerance in hybrid maize induced by seed priming with salicylic acid," Journal of Agronomy and Crop Science, vol. 194, no. 2, pp. 161-168, 2008.

[13] J. Nawaz, M. Hussain, A. Jabbar et al., "Seed priming a technique," The International Journal of Agriculture and Crop Sciences, vol. 6, pp. 1373-1381, 2013.

[14] Y.-j. Guan, J. Hu, X.-j. Wang, and C.-x. Shao, "Seed priming with chitosan improves maize germination and seedling growth in relation to physiological changes under low temperature stress," Journal of Zhejiang University Science B, vol. 10, no. 6, pp. 427-433, 2009.

[15] I. Afzal, S. M. A. Basra, M. Shahid, M. Farooq, and M. Saleem, "Priming enhances germination of spring maize (Zea mays L.) under cool conditions," Seed Science and Technology, vol. 36, no. 2, pp. 497-503, 2008.

[16] C. Bailly, "Active oxygen species and antioxidants in seed biology," Seed Science Research, vol. 14, no. 2, pp. 93-107, 2004.

[17] A. Ghoohestani, H. Gheisary, S. M. Zahedi, and A. Dolatkhahi, "Effect of seed priming of tomato with salicylic acid, ascorbic acid and hydrogen peroxide on germination and plantlet growth," International Journal of Agronomy and Plant Production, vol. 3, pp. 700-704, 2012.

[18] ISTA, "International rules for seed testing," International Seed Testing Association, Bassersdorf, Switzerland, 2019.

[19] S. Matthews and M. Khajeh Hosseini, "Mean germination time as an indicator of emergence performance in soil of seed lots of maize (Zea mays)," Seed Science and Technology, vol. 34, no. 2, pp. 339-347, 2006.

[20] Y.-S. Wang, S.-P. Tian, and Y. Xu, "Effects of high oxygen concentration on pro-and anti-oxidant enzymes in peach fruits during postharvest periods," Food Chemistry, vol. 91, no. 1, pp. 99-104, 2005.

[21] H. Ukeda, S. Maeda, T. Ishii, and M. Sawamura, "Spectrophotometric assay for superoxide dismutase based on tetrazolium salt $\quad 3^{\prime}-\{1-[($ Phenylamino $)$-carbonyl $]-3, \quad 4-$ tetrazolium\}-bis (4-methoxy-6-nitro) benzenesulfonic acid hydrate reduction by xanthine-xanthine oxidase," Analytical Biochemistry, vol. 251, no. 2, pp. 206-209, 1997.

[22] R. F. Beers and I. W. Sizer, "A spectrophotometric method for measuring the breakdown of hydrogen peroxide by catalase," The Journal of Biological Chemistry, vol. 195, no. 1, pp. 133140, 1952.

[23] M. M. Bradford, "A rapid and sensitive method for the quantitation of microgram quantities of protein utilizing the principle of protein-dye binding," Analytical Biochemistry, vol. 72, no. 1-2, pp. 248-254, 1976.

[24] A. L. Jiang, S. P. Tian, and Y. Xu, "Effects of controlled atmospheres with high- $\mathrm{O}_{2}$ or high $\mathrm{CO}_{2}$ concentrations on postharvest physiology and storability of "Napoleon" sweet cherry," Acta Botanica Sinica, vol. 44, pp. 925-930, 2002.

[25] A. A. Khan, "Preplant physiological seed conditioning," Horticultural Reviews, vol. 13, pp. 131-181, 1992.

[26] S. M. A. Basra, M. Farooq, R. Tabassam, and N. Ahmad, "Physiological and biochemical aspects of pre-sowing seed treatments in fine rice (Oryza sativa L.)," Seed Science and Technology, vol. 33, no. 3, pp. 623-628, 2005.

[27] L. Nie, H. Liu, L. Zhang, and W. Wang, "Enhancement in rice seed germination via improved respiratory metabolism under chilling stress," Food and Energy Security, p. e234. In press, 2020.

[28] C. A. Parera and D. J. Cantliffe, "Improved germination and modified imbibition of shrunken-2 sweet corn by seed disinfection and solid matrix priming," Journal of the American Society for Horticultural Science, vol. 116, no. 6, pp. 942-945, 1991.

[29] L. Gao and M. Yan, "Calcium chloride priming increases chilling tolerance in Salvia miltiorrhiza Bunge," Chilean Journal of Agricultural Research, vol. 80, no. 2, pp. 219-226, 2020. 
[30] I. Raskin, "Role of salicylic acid in plants," Annual Review of Plant Physiology and Plant Molecular Biology, vol. 43, no. 1, pp. 439-463, 1992.

[31] G.-z. Kang, Z.-x. Wang, K.-f. Xia, and G.-c. Sun, "Protection of ultrastructure in chilling-stressed banana leaves by salicylic acid," Journal of Zhejiang University Science B, vol. 8, no. 4, pp. 277-282, 2007.

[32] Z. Feng, A. Guo, and Z. Feng, "Amelioration of chilling stress by triadimefon in cucumber seedlings," Plant Growth Regulation, vol. 39, no. 3, pp. 277-283, 2003.

[33] A. S. Lukatkin, "Contribution of oxidative stress to the development of cold-induced damage to leaves of chillingsensitive plants: 3 . Injury of cell membranes by chilling temperatures," Russian Journal of Plant Physiology, vol. 50, no. 2, pp. 243-246, 2003.

[34] N. Suzuki and R. Mittler, "Reactive oxygen species and temperature stresses: a delicate balance between signaling and destruction," Physiologia Plantarum, vol. 126, no. 1, pp. 45-51, 2006.

[35] J. Fu and B. Huang, "Involvement of antioxidants and lipid peroxidation in the adaptation of two cool-season grasses to localized drought stress," Environmental and Experimental Botany, vol. 45, no. 2, pp. 105-114, 2001.

[36] D. A. Meloni, M. A. Oliva, C. A. Martinez, and J. Cambraia, "Photosynthesis and activity of superoxide dismutase, peroxidase and glutathione reductase in cotton under salt stress," Environmental and Experimental Botany, vol. 49, no. 1, pp. 69-76, 2003.

[37] A. Elkelish, H. Q. Sameer, S. A. M. Yasser et al., "Exogenous ascorbic acid induced chilling tolerance in tomato plants through modulating metabolism, osmolytes, antioxidants, and transcriptional regulation of catalase and heat shock proteins," Plants, vol. 9, pp. 1-21, 2020.

[38] L. Q. Li, J. Hu, Z. Y. Zhu, and J. Nkeshimana, "The effects of seed film coating with cold-tolerant agents on physiology and biochemistry changes of supersweet corn in low temperature stress," Journal of Zhejiang University (Agriculture and Life Science), vol. 30, no. 9, pp. 311-317, 2004, in Chinese.

[39] L.-J. Wang and S.-H. Li, "Salicylic acid-induced heat or cold tolerance in relation to $\mathrm{Ca}^{2+}$ homeostasis and antioxidant systems in young grape plants," Plant Science, vol. 170, no. 4, pp. 685-694, 2006.

[40] R. Chander and N. K. Kapoor, "High density lipoprotein is a scavenger of superoxide anions," Biochemical Pharmacology, vol. 40, no. 7, pp. 1663-1665, 1990.

[41] L.-J. Chen, H.-Z. Xiang, Y. Miao et al., "An overview of cold resistance in plants," Journal of Agronomy and Crop Science, vol. 200, no. 4, pp. 237-245, 2014.

[42] H. Li, S. Horke, and U. Förstermann, "Oxidative stress in vascular disease and its pharmacological prevention," Trends in Pharmacological Sciences, vol. 34, no. 6, pp. 313-319, 2013.

[43] M. Govindaraj, P. Masilamani, V. Alex Albert, and M. Bhaskaran, "Role of antioxidant in seed quality-a review," Agricultural Reviews, vol. 38, pp. 180-190, 2017.

[44] H.-M. Kang and M. E. Saltveit, "Chilling tolerance of maize, cucumber and rice seedling leaves and roots are differentially affected by salicylic acid," Physiologia Plantarum, vol. 115, no. 4, pp. 571-576, 2002.

[45] T. Janda, G. Szalai, K. Rios-Gonzalez, O. Veisz, and E. Páldi, "Comparative study of frost tolerance and antioxidant activity in cereals," Plant Science, vol. 164, no. 2, pp. 301-306, 2003.

[46] S. Agarwal, R. K. Sairam, G. C. Srivastava, A. Tyagi, and R. C. Meena, "Role of ABA, salicylic acid, calcium and hydrogen peroxide on antioxidant enzymes induction in wheat seedlings," Plant Science, vol. 169, no. 3, pp. 559-570, 2005.

[47] Ö. Turan and Y. Ekmekçi, “Activities of photosystem II and antioxidant enzymes in chickpea (Cicer arietinum L.) cultivars exposed to chilling temperatures," Acta Physiologiae Plantarum, vol. 33, no. 1, pp. 67-78, 2011.

[48] M. Janmohammadi, V. Enayati, and N. Sabaghnia, "Impact of cold acclimation, de-acclimation and re-acclimation on carbohydrate content and antioxidant enzyme activities in spring and winter wheat," Icelandic Agricultural Sciences, vol. 25, pp. 3-11, 2012.

[49] I. Ahmad, T. Khaliq, A. Ahmad, Sh.M. A. Basra, Z. Hasnain, and A. Ali, "Effect of seed priming with ascorbic acid, salicylic acid and hydrogen peroxide on emergence, vigor and antioxidant activities of maize," African Journal of Biotechnology, vol. 11, no. 5, pp. 1127-1132, 2012.

[50] A. Hameed, M. A. Sheikh, A. Hameed, T. Farooq, S. M. A. Basra, and A. Jamil, "Chitosan priming enhances the seed germination, antioxidants, hydrolytic enzymes, soluble proteins and sugars in wheat seeds," Agrochimica, vol. 7, pp. 31-46, 2013.

[51] H. Turk, S. Erdal, M. Genisel, O. Atici, Y. Demir, and D. Yanmis, "The regulatory effect of melatonin on physiological, biochemical and molecular parameters in coldstressed wheat seedlings," Plant Growth Regulation, vol. 74, no. 2, pp. 139-152, 2014. 